\title{
Analisis Kinerja Keuangan PT BPR Hasamitra
}

\author{
Marwah Yusuf ${ }^{1)}$ Anwar ${ }^{2)}$ \\ 12 Dosen Akuntansi, STIEM Bonagaya \\ email: marwah.yusuf@stiem-bongaya.ac.id
}

(Diterima: 1 Juli 2018; di revisi: 28 Agustus-2018; dipublikasikan: 31 Oktober-2018)

\begin{abstract}
Abstrak:
Penelitian ini bertujuan untuk menganalisis kinerja keuangan PT BPR Hasamitra, sebagai sebuah lembaga keuangan yang mengakar di nasabah Makassar. Juga untuk melihat apakah kinerja keuangan tersebut yang membuat Bank Perkreditan Rakyat ini bisa unggul dan eksis di Makassar.

Populasi penelitian adalah BPR Hasamitra di J1 Dr Wahidin Sudirohusodo kompleks pusat pertokoan No 5-6 Makassar, dengan menganalisis sampel laporan keuangan BPR Hasamitra. Selain itu, metode penelitian juga bisa dilakukan dengan wawancara langsung pihak BPR Hasamitra, terutama divisi yang terkait dengan pelaporan keuangan.

Berdasarkan hasil analisis maka ditemukan bahwa kinerja keuangan PT BPR Hasa Mitra berdasarkan rasio likuiditas mengalami kenaikan $181,19 \%$ tahun 2011, 166,77\% tahun 2010, sebelumnya 164,85\% di tahun 2009. Nilai LDR mengalami kenaikan $88,03 \%$ tahun $2011,85,60 \%$ tahun 2010 sebelumnya $83,13 \%$ ditahun 2009, hal ini disebabkan perbedaan pengakuan kredit, sehingga kredit yang diberikan lebih rendah dibanding dengan pinjaman yang diterima oleh BPR. Berdasarkan analisis rasio rentabilitas, ROE mengalami kenaikan 46,29\% tahun 2011, 46,04\% tahun 2010 sebelumnya 45,69\% di tahun 2009. Nilai NPM mengalami kenaikan 46,11\% tahun 2011, 44,36\% tahun 2010, sebelumnya $19,13 \%$ tahun 2009 , BOPO mengalami penurunan 39,33\% tahun 2011, 41,29\% tahun 2010, sebelumnya 74,02\% tahun 2009. Berdasarkan Berdasarkan analisis rasio solvabilitas, DER mengalami kenaikan $1.099,46 \%$ tahun 2011, $1.088,18 \%$ tahun 2010, sebelumnnya 1,034,75\% tahun 2009.
\end{abstract}

Keywords: Rasio Likuiditas, rasio rentabilitas, Rasio Solvabilitas, Kinerja keuangan

\section{PENDAHULUAN}

Menilai perkembangan suatu
perusahaan dapat dilakukan melalui
penganalisaan laporan keuangan. Dan kondisi keuangan suatu perusahaan akan dapat diketahui dari laporan keuangan perusahaan yang bersangkutan, yang terdiri dari neraca, laporan laba rugi, serta laporan keuangan lainnya. Dengan mengadakan analisa terhadap pos-pos neraca, kita dapat mengetahui gambaran terhadap laporan laba rugi, akan memberikan gambaran tentang hasil atau posisi keuangan perusahaan. Sedangkan menganalisa laporan laba rugi sebuah perusahaan, akan memberikan gambaran tentang hasil atau perkembangan usaha perusahaan yang bersangkutan.

Tujuan perusahaan untuk mendapatkan keuntungan (profit) yang optimal dari output yang dihasilkan. Dan itu sangat tergantung pada kapablitas para eksekutif dalam mengelola sumber daya perusahaan dengan baik ( good corporate governance). Suatu perusahaan dapat 
dianggap berhasil apabila secara terus menerus dapat memenuhi semua secara normal. Namun dapat dipungkiri bahwa antara perkembangan likuiditas dari profitabilitas sering timbul pertentangan.Hal ini terjadi disebabkan keinginan perusahaan mengejar keuntungan yang maksimal. Namun, di sisi lain potensi likuiditasnya diabaikan. Sebaliknya karena usaha untuk mempertahankan dan menjaga likuiditas yang tinggi, mengakibatkan laba yang dicapai menurun, disebabkan oleh banyaknya dana atau modal yang menganggur. Supaya perusahaan dapat mengontrol kontinuitas perusahaan, diperlukan adanya pertimbangan yang lebih rasional, di mana keseimbangan likuiditas di satu sisi dapat terjamin dan laba yang diharapkan juga dapat tercapai.

Untuk laporan keuangan suatu perusahaan, dapat dijadikan bahan penguji dari pekerjaan bagian pembukuan dan sebagai alat untuk menentukan atau menilai posisi keuangan suatu perusahaan pada waktu tertentu, dalam menganalisa kinerja keuangan perusahaan yang merupakan prestasi keuangan yang dicapai oleh perusahaan dalam periodeperiode tertentu.

Peranan perbankan dirasakan sangat penting dalam meningkatkan laju pertumbuhan ekonomi Indonesia. Tidak terkecuali, PT Bank Perkreditan Rakyat Hasamitra yang bergerak dalam usaha perbankan melayani tabungan, deposito, dan kredit, di mana turut berperan menunjang pelaksanaan pembangunan nasional, dalam rangka meningkatkan pemerataan, pertumbuhan ekonomi dan stabilitas nasional ke arah peningkatan taraf hidup rakyat banyak.

Sebagai salah satu lembaga keuangan, bank perlu menjaga kinerja agar beroperasi secara optimal. Salah satu cara untuk mengukur kinerja keuangan bank, dapat dilakukan dengan menggunakan rasio keuangan, misalnya rasio likuiditas, rasio solvabilitas maupun rentabilitas. Salah satu faktor yang harus diperhatikan oleh bank untuk bisa terus bertahan hidup adalah kinerja (kondisi keuangan) bank.

Berdasarkan pemaparan di atas, maka dilakukan penelitian dengan tujuan untuk mengetahui bagaimana kinerja keuangan BPR Hasamitra sebagai salah satu lembaga keuangan yang ada di Makassar.

\section{METODE}

\section{Pendekatan Penelitian}

Dalam penelitian ini peneliti menggunakan pendekatan penelitian kuantitatif. Metode yang digunakan adalah Metode penelitian deskriptif, metode deskriptif adalah metode yang digunakan untuk menggambarkan atau menganalisa suatu hasil penelitian tetapi tidak digunakan untuk membuat kesimpulan yang lebih luas (Sugiyono, 2011:29)..

\section{Definisi Konsep Penelitian}

Definisi konsep dalam penelitian ini sebagai berikut:

a. Kinerja keuangan adalah, gambaran setiap hasil ekonomi yang mampu diraih oleh perusahaan pada periode tertentu, melalui aktivitas-aktivitas perusahaan untuk menghasilkan keuntungan secara efisien dan 
efektif yang dapat diukur perkembangannya dengan mengadakan analisis terhadap datadata keuangan yang tercermin dalam laporan keuangan.

b. Rasio Keuangan adalah angka yang diperoleh dari hasil perbandingan dari satu pos laporan keuangan dengan pos lainnya yang mempunyai hubungan yang relevan dan signifikan (berarti).

\section{Objek Penelitian}

Objek penelitian ini adalah laporan keuangan PT Hasa Mitra, Tbk

\section{Metode Pengumpulan Data}

Metode pengumpulan data dalam penelitian ini dimaksudkan untuk memperoleh data yang relevan dan akurat dengan masalah yang dibahas, dengan cara memepelajari teoriteori, jurnal, artikel dan tulisan-tulisan di situssitus internet. Dan juga melakukan kunjungan langsung pada objek penelitian dengan cara observasi dengan mengadakan pengamatan langsung, wawancara dengan pihak-pihak yang berhubungan dengan yang diteliti, kemudian dengan dokumentasi dengan mengumpulkan dokumen-dokumen yang berkaitan dengan masalah yang diteliti.

\section{Metode Analisis Data}

Penelitian ini menggunakan metode analisis sebagai berikut:

\section{Analisis deskriptif}

Metode analisis deskriptif digunakan untuk menjelaskan dan menguraikan kinerja keuangan PT BPR Hasamitra Makassar.

\section{Analisis rasio}

Metode Analisis yang digunakan dengan menganalisis laporan keuangan pada tahun ( periode) tertentu, yaitu dengan membandingkan antara pos yang satu dan pos lainnya dalam laporan keuangan yang sama untuk tahun yang berbeda.

a. Rasio Likuiditas

1. Cash ratio merupakan alat liquid terdiri dari kas dan giro pada Bank Indonesia. Semakin tinggi rasio ini semakin tinggi pula kemampuan likuiditas bank yang bersangkutan, namun dalam prakteknya akan dapat mempengaruhi profitabilitas.

2. Loan to deposit ratio merupakan rasio yang digunakan untuk mengukur komposisi jumlah kredit yang diberikan dibandingkan dengan jumlah dana masyarakat dan modal sendiri yang digunakan.

b. Rasio Solvabilitas

Rasio DER adalah rasio yang digunakan untuk mengukur kemampuan bank dalam menutup sebagian atau seluruh utangutangnya, baik jangka panjang maupun jangka pendek, dengan dana yang berasal dari bank sendiri.

c. Rasio Rentabilitas

1. Rasio ROE merupakan indikator yang amat penting bagi para pemegang saham dan calon investor untuk mengukur kemampuan bank dalam memperoleh laba bersih yang dikaitkan dengan pembagian deviden.

2. Net profit margin merupakan rasio yang digunakan untuk mengukur kemampuan bank dalam menghasilkan 
net income dari kegiatan operasi pokoknya.

3. Rasio BOPO digunakan untuk mengukur tingkat efisiensi dan kemampuan bank dalam melakukan kegiatan operasinya. Rasio ini diperoleh dengan membagi biaya operasional dengan pendaparan operasional.

\section{HASIL DAN PEMBAHASAN}

Analisis Laporan Keuangan PT BPR Hasa Mitraadalah sebagai berikut :

a. Rasio Likuiditas

Berikut perhitungan rasio likuiditas yang dimiliki oleh PT BPR Hasamitra tahun 2011,2010 dan 2009 :

Tabel 1. Rasio Likuiditas

\begin{tabular}{|l|c|c|c|}
\hline Nama Rasio & 2011 & 2010 & 2009 \\
\hline $\begin{array}{l}\text { Cash } \\
\text { ratio(\%) }\end{array}$ & 181,19 & 166,77 & 164,85 \\
\hline LDR & 88,03 & 85,60 & 83,13 \\
\hline
\end{tabular}

Sumber : PT BPR Hasa Mitra, diolah

Berdasarkan perhitungan rasio likuiditas maka diketahui bahwa nilai cash ratio atau penilaian kemampuan BPR dalam membayar hutang jangka pendeknya mengalami kenaikan setiap tahunnya sebesar $164,85 \%$ tahun 2009 , 166,77\% tahun 2010 dan 181,19 tahun 2011. Hal ini disebabkan kenaikan jumlah aset likuidnya dibandingkan dengan kewajiban jangka pendek/segera jatuh tempo untuk tahun 2010 dan 2011, aset likuidnya termasuk di dalamnya pendapatan bunga yang akan diterima sebelumnya disajikan dalam asset lain-lain yang menambah asset likuid BPR, sehingga rasio lancarnya mengalami kenaikan di tahun 2010 dan 2011.
Sedangkan kewajiban jangka pendeknya termasuk di dalamnya hutang pajak tidak diakui adanya pajak tangguhan yang harus dilunasi, sebelumnya BPR Hasamitra mengakui adanya pajak tangguhan.

BPR Hasamitra mempunyai kinerja yang baik, karena mampu menjaga cash ratio berada di atas 22,56. Hal tersebut mengindikasi bahwa BPR Hasamitra di tahun 2010 dan 2011 mempunyai kinerja yang lebih baik dibanding di tahun 2009 .

LDR menunjukkan kemampuan bank dalam membayar kembali penarikan dana yang dilakukan deposan, dengan mengandalkan kredit yang diberikan mengalami kenaikan di setiap tahunnya sebesar $83,13 \%$ tahun $2009,85,60 \%$ di tahun 2010 dan 88,03 di tahun 2011. Ini disebabkan kredit yang diberikan lebih rendah dibandingkan dana dari pihak ketiga.

Untuk tahun 2010 dan 2011, perhitungan kredit sebesar pokok kredit dikurangi (-) provisi dan ditambah $(+)$ biaya transaksi yang diamortisasi secara garis lurus yang akan dibebankan dalam periode berjalan, untuk kredit selanjutnya sebesar baki debet dikurangi dengan amortisasi provisi ditambah amortisasi biaya transaksi, sebelumnnya kredit hanya sebesar pokok kredit, kredit selanjutnya sebesar baki kreditnya.

Perhitungan tersebut mengakibatkan kredit yang diberikan lebih rendah, sehingga berpengaruh terhadap rasio LDR-nya di tahun 2010 dan 2011. Walaupun demikian BPR Hasamitra mempunyai kinerja yang 
baik, karena mampu menjaga LDR tetap berada di bawah $94,75 \%$.

b. Rasio Solvabilitas

Analisis rasio solvabilitas PT BPR Hasa

Mitra dapat dilihat pada tabel 2 sebagai berikut :

Tabel 2. Rasio Solvabilitas

\begin{tabular}{|c|c|c|c|}
\hline $\begin{array}{c}\text { Nama } \\
\text { Rasio }\end{array}$ & 2011 & 2010 & 2009 \\
\hline DER (\%) & $1.099,46$ & $1.088,18$ & $1.034,75$ \\
\hline
\end{tabular}

Sumber : PT BPR Hasa Mitra, diolah

Dari tabel di atas nampak nilai DER mengalami kenaikan di setiap tahunnya sebesar $1.034,75 \%$ tahun 2009, 1.088,18\% di tahun 2010, 1.099,46\% di tahun 2011 peningkatan rasio DER ini menandakan bahwa kemampuan BPR untuk mentupi hutang-hutangnya dengan mengandalkan ekuitas yang ia miliki sangat kecil.

Untuk tahun 2010 dan 2011, pos kewajiban mengalami kenaikan, termasuk di dalamnya pinjaman yang diterima diakui nilai pokok ditambah (+) biaya transaksi sesuai prinsip historical cost, sebelumnya hanya dicatat sebesar nilai nominalnya tidak diperhitungkan biaya transaksinya, sama halnya dengan simpanan nasabah berupa tabungan dan deposito mengalami kenaikan diakui sebesar nilai nominal (+) dengan biaya transaksi, sebelumnnya hanya sebesar nilai nominal.

Dengan kata lain, bila mengandalkan ekuitas bank sebagai alat pembayaran hutang, maka hanya sebagian saja hutang yang mampu dilunasi. Untuk itu, tampaknya bank harus berusaha untuk memperbesar cadangan ekuitasnnya secara bijak (melakukan manajemen permodalan secara cermat), agar selain dapat memperbesar kemampuannya dalam membayar hutang, profitabilitas bank yang merupakan konsekuensi penggunaan ekuitas bank tidak akan terganggu secara signifikan.

c. Rasio Rentabilitas

Analisis Rasio Rentabilitas PT BPR Hasa Mitra dapat dilihat pada tabel 3 sebagai berikut :

\begin{tabular}{|l|c|c|c|}
\hline Nama Rasio & 2011 & 2010 & 2009 \\
\hline ROE (\%) & 46,29 & 46,04 & 45,69 \\
\hline NPM (\%) & 46,11 & 44,36 & 19,13 \\
\hline BOPO (\%) & 39,33 & 41,17 & 74,02 \\
\hline
\end{tabular}

Sumber : PT BPR Hasa Mitra, diolah

Dari perhitungan rasio rentabilitas diketahui nilai ROE mengalami kenaikan di setiap tahunnya sebesar $45,69 \%$ di tahun 2009, 46,04\% 2010, dan 46,29 di tahun 2011. Untuk tahun 2011, ekuitas yang dimiliki BPR mengalami kenaikan dikarenakan penambahan dana setoran model ekuitas sebesar 2.000.000.000 di tahun 2011, dinyatakan memenuhi ketentuan permodalan yang berlaku.

Namun, belum didukung dengan kelengkapan persyaratan untuk digolongkan sebagai modal disetor, sedangkan di tahun 2010 belum terdapat pos dana setoran modal ekiutas, karena belum memenuhi ketentuan permodalan yang berlaku.

BPR mampu meningkatkan tingkat laba dengan mengandalkan modal sendiri (ekuitas) yang dimiliki bank yang berarti bahwa BPR mempunyai kinerja yang baik. 
Nilai NPM mengalami kenaikan setiap tahunnya sebesar $19,13 \%$ di tahun 2009 , 44,36\% di tahun 2010 dan 46,11\% di tahun 2011. Untuk tahun 2011 provisi diakui sebagai pendapatan untuk kredit demikian juga biaya transaksi, selain itu BPR Hasamitra tidak mengakui adanya pajak tangguhan yang diakui sebesar pajak yang harus dibayar pada periode berjalan.

Sebelumnnya provisi dan biaya transaksi diakui sekaligus sebagai pendapatan non bunga. Hal tersebut mengindikasi bahwa BPR Hasamitra dapat mengoptimalkan pendapatan operasionalnya, yang berarti kinerja operasionalnya tahun 2010 dan 2011 lebih baik atas laporan keuangan dibandingkan tahun 2009.

Nilai BOPO mengalami penurunan di setiap tahunnya sebesar $74,02 \%$ di tahun 2009, 41,17\% di tahun 2010 dan 39,33 di tahun 2011 untuk tahun 2010 dan 2011, beban operasional tidak termasuk di dalamnya beban bunga. Beban bunga tersebut disajikan langsung sebagai pengurang pendapatan bunga, yang mengakibatkan beban operasional lebih rendah dari sebelumnya.

Selain itu, biaya transaksi tidak diakui sebagai pendapatan operasional BPR Hasamitra. BPR Hasamitra mampu menjaga BOPO tetap berada di bawah 93,52 \%, hal tersebut mengindikasikan bahwa BPR Hasamitra mempunyai kinerja yang lebih baik di tahun 2010 dan 2011 dibanding tahun 2009.

\section{KESIMPULAN DAN SARAN}

Berdasarkan dari hasil penelitian dan pembahasan maka dapat ditarik kesimpulan sebagai berikut :

1. Analisis kinerja keuangan berdasarkan rasio likuiditas cash ratio mengalami kenaikan sebesar $181,19 \%$ tahun $2011,166,77 \%$ tahun 2010, sebelumnya $164,85 \%$ di tahun 2009 . Hal ini disebabkan kenaikan dalam aset likuidnya termasuk di dalamnya pendapatan bunga yang akan diterima, sebelumnya disajikan dalam asset lain-lain, sehingga menambah aset likuidnya. LDR mrngalami kenaikan $88,03 \%$ tahun $2011,85,60 \%$ tahun 2010 sebelumnya $83,13 \%$ ditahun 2009 , hal ini disebabkan perbedaan pengakuan kredit, sehingga kredit yang diberikan lebih rendah dibanding dengan pinjaman yang diterima oleh BPR. Walaupun demikian, BPR Hasamitra mempunyai kinerja yang baik, karena mampu menjaga LDR tetap berada di bawah $94,75 \%$.

2. Analisis rasio rentabilitas, ROE mengalami kenaikan 46,29\% tahun 2011, $46,04 \%$ tahun 2010 sebelumnya 45,69\% di tahun 2009, disebabkan penambahan dana setoran modal ekuitas, sehingga menambah ekuitas BPR hasamitra, sebelumnya pos tersebut belum diatur. NPM mengalami kenaikan 46,11\% tahun 2011, 44,36\% tahun 2010, sebelumnya $19,13 \%$ tahun 2009, disebabkan provisi diakui sebagai pendapatan untuk kredit, demikian juga biaya transaksi. Selain itu, BPR Hasamitra tidak mengakui adanya pajak tangguhan yang diakui sebesar pajak yang harus dibayar pada periode berjalan. Sebelumnya, provisi dan 
biaya transaksi diakui sekaligus sebagai pendapatan non bunga. BOPO mengalami penurunan $39,33 \%$ tahun $2011,41,29 \%$ tahun 2010, sebelumnya 74,02\% tahun 2009 disebabkan beban operasional tidak termasuk di dalamnya beban bunga, beban bunga tersebut disajikan langsung sebagai pengurang pendapatan bunga, yang mengakibatkan beban operasional lebih rendah, selain itu biaya transaksi tidak diakui sebagai pendapatan operasional BPR Hasamitra.

3. Analisis analisis rasio solvabilitas, DER mengalami kenaikan $1.099,46 \%$ tahun 2011, 1.088,18\% tahun 2010, sebelumnnya $1,034,75 \%$ tahun 2009. Hal tersebut disebabkan kewajiban mengalami kenaikan termasuk di dalamnya simpanan nasabah berupa tabungan dan deposito dan pinjaman yang diterima diakui sebesar nilai nominal ditambah (+) dengan biaya transaksi, sesuai dengan prinsip historical cost. Sebelumnya hanya sebesar nilai nominal.

Berdasarkan hasil pembahasan dan kesimpulan yang telah dikemukakan oleh peneliti, maka saran yang dapat diajukan dalam penelitian ini untuk dijadikan bahan masukan yang berguna bagi pihak yang terkait, yaitu sebaiknya BPR Hasamitra tetap menjaga peningkatan kinerja keuangan atas laporan keuangan. Dengan meningkatkan kredit yang diberikan untuk memperoleh pinjaman dari pihak ketiga, serta memperbesar cadangan ekuitasnya secara bijak (melakukan manajemen permodalan secara cermat), agar selain dapat memeperbesar kemampuannya dalam membayar hutang, profitabilitas bank yang merupakan konsekuensi penggunaan ekuitas bank, tidak akan terganggu secara signifikan.

\section{DAFTAR RUJUKAN}

Bank Indonesia. Desember 2009. Surat Edaran kepada Semua Bank Perkreditan Rakyat di Indonesia. Bank Indonesia, Jakarta.

Basir, Syarief. Juli 2010. Persiapan Penerapan PSAK ETAP. Kantor Akuntan Publik Syarief. Basir dan Rekan, Jakarta.

Dewan Standar Akuntansi Keuangan, 2009. Standar Akuntansi Keuangan Exposure Draft PSAK 1 (Revisi 2009) tentang Penyajian Laporan Keuangan. Ikatan Akuntan Indonesia, Jakarta.

Faisol, Ahmad, 2007. Analisis Kinerja Keuangan Bank pada PT Bank Muamalat Indonesia Tbk, Jurnal Ilmiah Berkala Empat Bulanan, Vol 3, No. 2, pp.129-170.

Kasmir. 2013. “Analisis Laporan Keuangan”. Edis 1. Cetakan ke-6. Jakarta: Rajawali Pers.

Harahap, Sofyan Syafri. 2009. Analisis Kritis atas Laporan Keuangan. Rajawali.

Indra Bastian, Suhardjono. 2006. Akuntansi Perbankan. Jakarta: Salemba Empat.

Institut Akuntan Indonesia, 2012. Panduan Penyusunan Laporan Keuangan Berdasarkan Standar Akuntansi Keuangan Entitas Tanpa Akuntabilitas Publik: ILUSTRASI LAPORAN KEUANGAN PT ETAP INDONESIA, Jakarta.

Jusuf, Jopie, 2008. Analisis Kredit untuk Account Officer. PT Gramedia Pustaka Utama. Jakarta.

Purba, Mansurya Tenno, Sucipto, 2009. Analisa Rasio Keuangan sebagai Pengambilan Keputusan pada PT Intraco Penta Tbk. Medan. Jurnal Akuntansi Universitas Sumatera Utara.

Rudianto. 2009. "Pengantar Akuntansi". Cetakan Pertama. Jakarta: Erlangga.

Salam, Adityawan, 2010. Analisis Persepsi Akuntan terhadap Standar Akuntansi Keuangan Entitas tanpa Akuntabilitas Publik (SAK ETAP) Makassar Jurusan Akuntansi Universitas Hasanuddin.

Tim Pedoman Akuntansi Bank Perkreditan Rakyat Bank Indonesia 2010. 